\title{
46. MUD VOLCANIC SAMPLES IN THE CONTEXT OF THE MEDITERRANEAN RIDGE MUD DIAPIRIC BELT ${ }^{1}$
}

\author{
Grigorii G. Akhmanov² and John M. Woodside ${ }^{3}$
}

\begin{abstract}
Mud volcanism on the Mediterranean Ridge has been the object of intensive investigation during Training Through Research (TTR) expeditions in 1993, 1994, and 1995 (Gelendzhik and Professor Logachev cruises). As a result, a large database has been compiled on the lithology of mud volcano deposits exposed on the seafloor.

The Ocean Drilling Program (ODP) holes that were drilled during Leg 160 within the Olimpi Area, the most studied mud diapiric area of the Mediterranean Ridge, have allowed us for the first time to look deeper into the mud volcanoes and to analyze some peculiarities of their development since the Pliocene.

The composition of buried mud breccias that were recovered during Leg 160 was found to be rather typical of the Olimpi area, as determined from the earlier TTR investigations. Significant differences between buried breccia and mud breccia exposed on the seafloor were not observed. Most of the mud breccia clast types previously described for exposed mud breccia flows of the Olimpi area were found in the ODP samples. No new types were observed in the buried and older mud breccias.

Mudstones are prevalent among rock fragments of the mud breccia samples recovered by ODP as well as in exposed Olimpi mud breccia. Micrites, fossiliferous micrites, and packed biomicrites are as widespread among lithoclasts of the limestone group as in the youngest mud breccia flows. The different sandstone fragments observed in the ODP mud breccia samples correspond to the subfeldspathic lithic wackes and lithic arenites previously described from the Olimpi area. The crystalloclasts have all resulted from disintegration of different rock fragments within the mud breccia. The set of crystalloclasts corresponds completely to component compositions of the lithoclasts. The Olimpi mud breccia matrix examined in both Leg 160 samples and TTR samples is similar and mainly composed of smectite and mixed-layered (illite/smectite with prevalent smectite layers) clay minerals $(40 \%-65 \%)$, kaolinite $(15 \%-30 \%)$, and illite $(10 \%-30 \%)$. The lack of significant downhole variation in mud breccia composition suggests that the source formations for the Olimpi mud breccia have not changed since at least the late Pliocene.

Comparisons of the compositions of the Olimpi mud breccia (on the basis both of ODP and previous data) with mud breccias from other known diapiric area on the Mediterranean Ridge exhibit some differences. The differences reflect peculiarities of source formation lithology and structural tectonic setting of mud volcanoes in different areas of the Eastern Mediterranean. There are also common features of the Mediterranean mud breccia, which indicate that some common sedimentary series extend through the whole Eastern Mediterranean.
\end{abstract}

\section{INTRODUCTION}

Mud volcanism on the Mediterranean Ridge has attracted the attention of scientists for almost $20 \mathrm{yr}$, since 1978, when the first Mediterranean mud diapir was discovered west of Crete (Cita et al., 1981). Since then, intensive investigation of these phenomena has resulted in the discovery of numerous new mud volcanoes on the crest of the Mediterranean Ridge (Limonov et al., 1996) (Fig. 1). As a result, a large data base has been compiled on the lithology of mud volcano deposits that are exposed on the seafloor or overlain by a thin veneer of Holocene ooze (see Cita et al., 1996, for a review and relevant references). Ocean Drilling Program (ODP) holes drilled during Leg 160 were within the most studied mud diapiric area of the Eastern Mediterranean and have allowed us for the first time to look deeper into the mud volcanoes and to analyze some peculiarities of their development since the Pliocene. In this paper, we report the results of an investigation of the mud breccia samples from the Milano and Napoli mud volcanoes drilled during Leg 160. These data are compared with those from studies of large volumes of mud breccia collected during UNESCO Training Through Research (TTR) expeditions to the mud volcano fields on the Mediterranean Ridge in 1993,

${ }^{1}$ Robertson, A.H.F., Emeis, K.-C., Richter, C., and Camerlenghi, A. (Eds.), 1998. Proc. ODP, Sci. Results, 160: College Station, TX (Ocean Drilling Program).

${ }^{2}$ Faculty of Geology, Moscow State University, Moscow, Russia.

${ }^{3}$ Correspondence author: Faculty of Earth Sciences, Free University, De Boelelaan 1085, 1081 MV Amsterdam, The Netherlands.wooj@geo.vu.nl
1994, and 1995 (Gelendzhik and Professor Logachev cruises). Thus, the ODP data are placed in their regional context and linked with the ODP site survey data obtained during the TTR Program. The aims and methodology of the research were the following:

1. recognition of the main mud breccia types on the basis of their structural and textural characteristics and interpretation of peculiarities of genesis of each type;

2. determination of mud breccia composition;

3. comparison of the compositions of the Olimpi mud breccia (on the basis of both ODP and previous data) with mud breccias from other known diapiric area on the Mediterranean Ridge;

4. description of lithological and fabric variations of the mud breccia sampled downhole, which are presented in vertical section.

\section{MATERIALS AND METHODS}

A lithologic study of 37 samples of mud breccias and pelagic sediments from Sites 970 (Milano mud volcano) and 971 (Napoli mud volcano) was performed in the laboratories of Moscow State University. To identify the composition and structural and textural features, thin-section samples were examined under polarizing microscope. The core descriptions carried out on board during Leg 160 (Emeis, Robertson, Richter, et al., 1996) also provided the support for structural investigations and interpretation of data. 


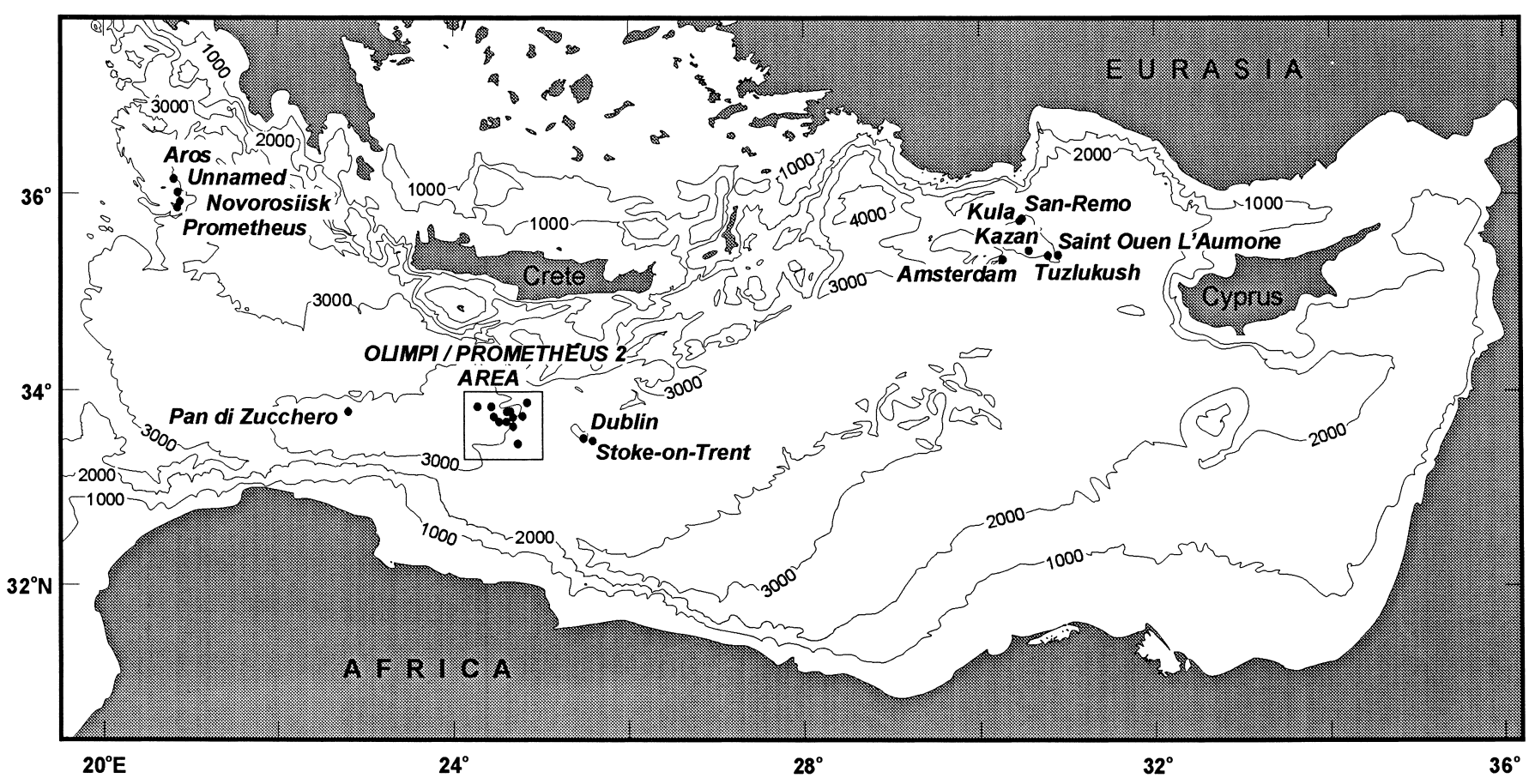

Figure 1. Location of the Mediterranean Ridge mud volcanoes (isobaths every $1000 \mathrm{~m}$ ). See Figure 2 for detailed position of the mud volcanoes of the Olimpi/ Prometheus 2 Area.

Investigation of mud breccia composition is mainly based on comparison with data previously obtained from this area (Akhmanov, 1996), when there was an opportunity to examine large amounts of mud breccia in detail and to study much larger clasts. Using characteristics such as structure, texture, composition, and lithology, three main types of mud volcanic deposits were defined for the samples recovered at the ODP sites. Lithological and fabric variations of the sampled mud breccia with depth below the seafloor were then considered.

The principal clay mineral composition of matrix from buried mud breccia was identified on the basis of X-ray analysis for comparison with data obtained from mud breccia flows exposed on the seafloor.

\section{MUD BRECCIA LITHOLOGY}

The term mud breccia lithology as used here encompasses (1) mud breccia composition (including mud clast lithologies and mud breccia matrix), and (2) sedimentary structures of the mud volcanic deposits.

\section{Mud Breccia Composition}

Mud volcanic deposits are represented by a very complex mixture of material from the sedimentary successions through which the mud volcanoes erupted. Mud breccia, therefore, provides important information about the composition of the deep-seated formations of the Mediterranean Ridge. In studying the mud breccia, we deal with fragments of rocks that were deposited millions of years ago, subsequently buried, and are now situated at depths up to a few kilometers (Camerlenghi et al., 1995).
Mud breccia consists of a clayey and silt-sized matrix with abundant coarser clasts of terrigenous and biogenic material, and claystone fragments that are more consolidated than the matrix.

\section{Mud Breccia Clast Lithologies}

The clasts from Leg 160 samples can be divided into several groups: lithoclasts (fragments of different rocks), crystalloclasts (grains of minerals), and bioclasts (foraminifers, shell fragments, etc.). Fragments of mudstones predominate within the lithoclasts. They are tabular or bladed, very thinly laminated, and soft. The shape and structure of some mudstone fragments imply plastic deformation of the fragments within the mud breccia. The size of mudrock fragments varies from 0.5 to $10 \mathrm{~mm}$. Clay particles commonly show strict orientation that results in almost simultaneous extinction in the entire thin section of fragment.

Fragments of micritic limestones are abundant. They are massive, structureless, equant, rounded, and sometimes clay rich as well as rich in organic matter, and range in diameter from 1 to $3 \mathrm{~mm}$. Fossiliferous micrites are composed of Globigerina in a micritic calcite matrix with a clay admixture. Fragments of packed biomicrites were also observed in several of the samples studied.

Siltstones, fine-grained sandstones with a clayey matrix, and finegrained sandstones with calcite cement are also present as mud breccia clasts. They are structureless, massive, usually angular, and form a variety of shapes. Their size range is $1-3 \mathrm{~mm}$.

Polycrystalline aggregates of calcite are mainly angular, structureless, of various size, and abundant. They are probably fragments of calcite veins from carbonate rocks, which were crushed during mud breccia formation. Quartz grains are prevalent among crystalloclasts. They vary in shape, size, and roundness. Plagioclase grains and potassium-feldspar grains are less abundant and are usually less than $0.1 \mathrm{~mm}$ in size. Altered grains are commonly rounded, whereas 
relatively "fresh" grains are subangular. Monocrystals of calcite, rare muscovite, and glauconite grains were also observed. Bioclasts in the samples studied are represented only by planktonic foraminifers and fragments of their chamber walls, which are usually filled by spar calcite.

These main lithological groups of clasts are present in all mud breccia samples, with some rare exceptions that are explained by the small amount of material available for this study (Table 1). No significant variations in the mud breccia clast lithology were noted downhole.

\section{Mud Breccia Matrix}

Mud breccia matrix consists of clay minerals with an admixture of fine, silt-sized grains of quartz, calcite, and feldspar.

The matrix clay mineral composition of the buried mud breccias sampled during Leg 160 was defined on the basis of X-ray studies. The matrix is mainly composed of smectite and mixed-layered (illite/ smectite with prevalent smectite layers) clay minerals (44\%-66\%), kaolinite $(17 \%-30 \%)$, and illite $(14 \%-30 \%)$. No significant variations in clay mineral composition of the matrix were noted downhole or between different volcanoes except for one sample (160-970A$9 \mathrm{X}-1,20-22 \mathrm{~cm})$ that is composed predominantly of illite $(45 \%)$ and relatively small amounts of smectite $(27 \%)$. Our explanation of this composition is that a mudstone fragment was probably analyzed instead of the matrix sample.

The clay mineral composition of the mud breccia matrix from Leg 160 samples corresponds exactly with the results of matrix studies previously carried out for the Olimpi Area mud volcanoes from TTR3 data (G.G. Akhmanov, unpubl. data) (Table 2).

Angular, fine, silt-sized grains of quartz, calcite, and feldspar provide a constant admixture to the predominantly clayey matrix of the mud breccia. Moreover, the subdivision of the mud breccia into matrix and clasts is subjective because of very poor sorting. No clear granulometric boundary divides matrix from clasts in the mud breccias. All grain-size classes are well represented. This may be ex- plained by considering the processes of mud breccia formation in terms of the gradual mechanical and chemical breakdown of clasts as they are brought to the seafloor from depth.

Mud breccia formation is believed to begin at the depth of the sedimentary source deposits. A plastic, mostly clayey, sedimentary series is forced up to the seafloor under overpressure. During its upward migration through overlying deposits, it mechanically assimilates fragments of rocks that surround the conduit to the seafloor. Mud breccia development continues after deposition on the seafloor where chemical alteration occurs with further disaggregation of clasts. Composition of the mud breccia matrix is changed in time by the assimilation of clasts.

Thin-section investigations of clast-matrix contacts and matrix texture and composition were conducted to characterize the tendencies of different clast types to disintegrate and become incorporated in the matrix.

Soft and plastic mudstone fragments are important in the formation of the matrix. Transformation of these clasts into matrix material forms an entire succession. Micrites and fossiliferous micrites also participate in matrix formation, although they are more indurated than the mudstones. Siliciclastic rocks can disaggregate and transform into matrix as well. Crystalloclasts (quartz grains, feldspar grains, etc.) are generally the result of disintegration of source rocks that gradually become incorporated into the matrix. Mineral grains behave in the matrix according to their chemical stabilities. Quartz grains that are the most stable remain almost intact, whereas feldspar grains may be replaced by clay minerals or calcite. Complete replacement produces pseudomorphs after feldspar, which may then dissolve in the matrix.

According to their behavior in the matrix, the mud breccia clasts can be arranged as a series from the least to the most stable: soft and plastic claystones and mudstones, micrites and fossiliferous micrites, siltstones, sandstones, fragments of calcite crack fillings, feldspar grains, mica, calcite grains, chalcedony, polycrystalline quartz grains, and monocrystalline quartz grains, respectively. The compositions of mud breccia matrix and enclosed clasts are closely related.

Table 1. Mud breccia clasts observed in samples studied.

\begin{tabular}{|c|c|c|c|c|c|c|c|c|c|c|c|c|}
\hline \multirow[b]{2}{*}{$\begin{array}{l}\text { Core, section, } \\
\text { interval }(\mathrm{cm})\end{array}$} & \multicolumn{7}{|c|}{ Lithoclasts } & \multicolumn{4}{|c|}{ Crystalloclasts } & \multirow[b]{2}{*}{ Bioclasts } \\
\hline & Mudstone & $\begin{array}{l}\text { Sandstone with } \\
\text { clayey matrix }\end{array}$ & $\begin{array}{l}\text { Sandstone with } \\
\text { calcite cement }\end{array}$ & Siltstone & $\begin{array}{c}\text { Packed } \\
\text { biomicrite }\end{array}$ & Micrite & $\begin{array}{l}\text { Fossiliferous } \\
\text { micrite }\end{array}$ & Quartz & Plagioclase & K-feldspar & Calcite & \\
\hline \multicolumn{13}{|l|}{ 160-970A- } \\
\hline $1 \mathrm{H}-4,60-62$ & + & + & + & + & + & + & & + & + & + & + & + \\
\hline $2 \mathrm{H}-1,60-62$ & + & + & + & + & + & + & + & + & + & + & + & + \\
\hline $7 X-1,23-25$ & + & + & + & & + & + & & + & + & + & + & + \\
\hline $9 \mathrm{X}-1,20-22$ & + & & & + & + & + & & + & + & + & + & + \\
\hline $13 X-1,10-12$ & + & + & & + & & + & + & + & + & + & + & + \\
\hline $15 X-1,60-62$ & + & + & + & + & + & + & + & + & + & + & + & + \\
\hline $18 X-2,60-62$ & + & + & & & & + & + & + & + & + & + & + \\
\hline $19 X-2,60-62$ & + & & & + & & + & & + & + & + & + & + \\
\hline $20 \mathrm{X}-1,60-62$ & + & + & & + & + & + & + & + & + & + & + & + \\
\hline \multicolumn{13}{|l|}{ 160-970C- } \\
\hline $3 \mathrm{H}-1,15-17$ & + & & + & + & & + & + & + & & + & + & + \\
\hline $3 \mathrm{H}-4,80-82$ & + & + & & + & & + & & + & + & + & + & + \\
\hline \multicolumn{13}{|l|}{ 160-970D- } \\
\hline $1 \mathrm{H}-2,20-22$ & + & & & + & & + & & + & + & + & + & + \\
\hline $4 \mathrm{H}-2,24-26$ & + & & + & + & & + & + & + & + & + & + & + \\
\hline $5 \mathrm{H}-4,90-92$ & + & + & + & + & & + & & + & & & & + \\
\hline \multicolumn{13}{|l|}{$160-971 \mathrm{~A}-$} \\
\hline $3 \mathrm{H}-3,23-25$ & + & + & + & + & + & + & + & + & + & + & + & + \\
\hline $6 \mathrm{X}-1,4-6$ & + & & & + & & + & & + & + & + & + & + \\
\hline 9X-CC, 9-11 & + & & & & & + & + & + & & + & + & + \\
\hline \multicolumn{13}{|l|}{ 160-971B- } \\
\hline $4 \mathrm{H}-1,5-7$ & + & + & & + & & + & & + & & + & + & + \\
\hline $7 X-1,5-7$ & + & + & & + & + & + & + & + & & + & + & + \\
\hline $12 X-1,9-11$ & + & & + & & + & + & + & + & + & + & + & + \\
\hline $16 \mathrm{X}-2,19-21$ & + & + & & + & & + & + & + & + & + & + & + \\
\hline $19 X-3,21-23$ & + & + & & + & & + & & + & & + & + & + \\
\hline $22 X-1,5-7$ & + & & & & + & + & + & + & & + & + & + \\
\hline
\end{tabular}

Note: $+=$ found in sample. 
Table 2. Clay mineral composition of mud breccia matrix sampled during Leg 160 and TTR cruises.

\begin{tabular}{|c|c|c|c|}
\hline $\begin{array}{l}\text { Core, section, } \\
\text { interval }(\mathrm{cm})\end{array}$ & $\begin{array}{c}\text { Kaolinite } \\
(\%)\end{array}$ & $\begin{array}{l}\text { Illite } \\
(\%)\end{array}$ & $\begin{array}{l}\text { Smectite* } \\
(\%)\end{array}$ \\
\hline $\begin{array}{c}160-970 \mathrm{~A}- \\
1 \mathrm{H}-4,60-62 \\
2 \mathrm{H}-1,60-62 \\
7 \mathrm{X}-1,23-25 \\
9 \mathrm{X}-1,20-22 \\
13 \mathrm{X}-1,10-12 \\
15 \mathrm{X}-1,60-62 \\
18 \mathrm{X}-2,60-62 \\
19 \mathrm{X}-2,60-62 \\
20 \mathrm{X}-1,60-62\end{array}$ & $\begin{array}{l}22 \\
21 \\
30 \\
28 \\
20 \\
24 \\
19 \\
22 \\
21\end{array}$ & $\begin{array}{l}17 \\
16 \\
21 \\
46 \\
27 \\
24 \\
25 \\
15 \\
22\end{array}$ & $\begin{array}{l}61 \\
63 \\
50 \\
27 \\
52 \\
52 \\
56 \\
64 \\
56\end{array}$ \\
\hline $\begin{array}{l}\text { 160-970C- } \\
3 \mathrm{H}-1,15-17 \\
3 \mathrm{H}-4,80-82\end{array}$ & $\begin{array}{l}20 \\
23\end{array}$ & $\begin{array}{l}25 \\
27\end{array}$ & $\begin{array}{l}55 \\
50\end{array}$ \\
\hline $\begin{array}{l}\text { 160-970D- } \\
1 \mathrm{H}-2,20-22 \\
4 \mathrm{H}-2,24-26 \\
5 \mathrm{H}-4,90-92\end{array}$ & $\begin{array}{l}21 \\
20 \\
18\end{array}$ & $\begin{array}{l}14 \\
30 \\
24\end{array}$ & $\begin{array}{l}66 \\
50 \\
58\end{array}$ \\
\hline $\begin{array}{c}160-971 \mathrm{~A}- \\
3 \mathrm{H}-3,23-25 \\
6 \mathrm{X}-1,4-6\end{array}$ & $\begin{array}{l}24 \\
30\end{array}$ & $\begin{array}{l}22 \\
26\end{array}$ & $\begin{array}{l}54 \\
44\end{array}$ \\
\hline $\begin{array}{l}160-971 \mathrm{~B}- \\
4 \mathrm{H}-1,5-7 \\
7 \mathrm{X}-1,5-7 \\
12 \mathrm{X}-1,9-11 \\
16 \mathrm{X}-2,19-21 \\
19 \mathrm{X}-3,21-23 \\
22 \mathrm{X}-1,5-7\end{array}$ & $\begin{array}{l}27 \\
21 \\
17 \\
24 \\
24 \\
20\end{array}$ & $\begin{array}{l}20 \\
21 \\
25 \\
24 \\
23 \\
25\end{array}$ & $\begin{array}{l}53 \\
58 \\
58 \\
52 \\
54 \\
55\end{array}$ \\
\hline Olimpi Area, TTR data & $15-30$ & $10-30$ & $40-65$ \\
\hline
\end{tabular}

Note: $*$ sum of smectite and mixed-layered (illite/smectite) clay minerals with prevalent smectite layers.

\section{Sedimentary Structures of Mud Volcanic Deposits}

Although mud breccia composition does not vary significantly with depth below the seafloor, its structural diversity as observed in thin section does vary. Three main types of mud breccia were described according to their structural features. The main sedimentological characteristics of the mud breccia types are summarized in Table 3 .

1. The most widespread mud breccia type is represented by a very poorly sorted, matrix-supported, massive, unlayered, ungraded mixture of clay matrix with abundant clasts that vary in composition, shape, size, and roundness. The clast size in the samples studied varies from 0.01 to $10 \mathrm{~mm}$, but most clasts are between 0.1 and $2 \mathrm{~mm}$ in size. Clasts show no preferred orientation. The matrix consists of calcite, clay minerals, and fine silt-sized grains of quartz and feldspar. Mud breccia of this type dominates and forms the central parts of mud breccia flows (i.e., middle parts of individual beds). This type of mud breccia is the most commonly occurring; thus, we refer to it as "ordinary mud breccia."

2. In contrast to structureless, ordinary mud breccia, a second type of mud volcanic deposit is organized. Mud breccia of this type displays a preferred orientation of bladed grains. Deformation of soft, plastic fragments of clay and mudstones is common. Breccia of this type is associated with the outer extremities of mud breccia flows (i.e., toward the bed contacts). Usually, this breccia shows an increase in carbonate content toward the contacts because of partial mixing of adjacent high-carbonate deposits. Sorting of this breccia also increases toward the contact. Large clasts are almost absent; grains up to $2 \mathrm{~mm}$ in size dominate. We use the term "organized mud breccia" for such deposits.

3. A third type of mud volcanic facies observed in the samples from Leg 160 may not really be a mud volcano breccia in the strict sense, although it originated from the mud breccia deposits. Intervals of such deposits were interpreted as coarse-grained turbidites during Leg 160 shipboard investigation (Emeis, Robertson, Richter, et al., 1996). This type of deposits is represented by clast-supported facies that shows fine, planar lamination. Some samples are graded, and clasts show a preferred orientation. In contrast to ordinary breccia facies, relatively good sorting is observed, especially in the fine-grained samples. The structural and textural features imply transportation of material by a more liquid gravity flow (i.e., probably a turbidity current) than most common mud breccia flows. The component composition of the deposits is the same as for typical ordinary mud breccia. Clasts of all lithologies, described for the ordinary mud breccia, were observed in samples of these sediments: micrites, fossiliferous micrites, sandstones, claystones, and all types of crystalloclasts. Matrix composition is almost the same as that of ordinary mud breccia as well. The deposits were formed by gravity flows transporting material derived from ordinary breccia. This material was sorted during its transportation and redeposited as local turbidites not far from a source area (e.g., the mud volcano crater or the upper slope of the mud volcano). We refer to these sediments as "redeposited mud breccia." The redeposited mud breccias were described for intervals around $170 \mathrm{~m}$ below seafloor (mbsf) of the outer flanks of the Milano mud volcano (Hole 970A) and the Napoli mud volcano (Hole 971B). Redeposition of mud breccias in this way might be related to some period of tectonic activity in the area. We must note here that the microstructural types of mud breccia, proposed above on the basis of thin-section study of the ODP samples, are different from the lithological types that were identified by Staffini et al. (1993) on the basis of the visual description of the Olimpi and Prometheus 2 mud breccia.

\section{DISCUSSION}

The Olimpi diapiric field was the most studied area of mud volcanism on the Mediterranean Ridge, even before Leg 160. Numerous national and international expeditions have discovered 23 dome-like structures there, 16 of which were sampled and found to contain mud breccia (Fig. 2). Some peculiarities of exposed mud breccia lithology from this area were described in a series of publications (Cita et al., 1989; Camerlenghi et al., 1992; Staffini et al., 1993; Cita et al., 1994; Akhmanov, 1996; Premoli-Silva et al., 1996; van der Meer, 1996). ODP samples have given us a unique opportunity to investigate the nature of buried mud breccia flows, thus providing data on possible time variations in mud volcanism.

The composition of buried mud breccias recovered during Leg 160 were found to be rather typical of the Olimpi area as determined from earlier studies. That significant differences from mud breccia exposed on the seafloor were not observed is an important result of this research. Most of the lithoclast types previously described for exposed mud breccia flows of the Olimpi area were found in the ODP samples. No new types were observed in the buried older mud breccia. The approximate percentage composition of mud breccia deposits from both the ODP and other data sets is almost the same.

Table 4 summarizes the comparison between the lithoclasts observed in ODP samples from buried mud breccia and the types of rock fragments previously described for the Olimpi mud breccia exposed on the seafloor. The two sets of lithoclasts and their lithologies are almost identical.

Mudstone is prevalent among the clasts of the mud breccia samples recovered by ODP, as well as in Olimpi mud breccia sampled previously by seafloor coring operations. Micrites and fossiliferous micrites are as widespread among lithoclasts of the limestone group 
Table 3. Sedimentological characteristics of the Olimpi area mud breccia sampled from Leg 160 by definition in thin section.

\begin{tabular}{llll}
\hline & \multicolumn{1}{c}{ "Ordinary" mud breccia } & \multicolumn{1}{c}{ "Organized" mud breccia } & "Redeposited" mud breccia \\
\hline Structure & Massive & Massive & Finely planar laminated or graded \\
Fabric & Matrix-supported & Matrix-supported & Clast-supported \\
Sorting & Very poorly sorted & From poorly to well sorted towards contacts & Moderately sorted \\
Clast orientation & No orientation & Preferred orientation of bladed grains & No orientation \\
Position & Inner part of mud breccia flow & Upper and lower parts of mud breccia flows Outer flanks of mud volcanoes \\
& Mud breccia of inner part of flow & Mud breccia of upper or lower parts of flow Local gravity flows from crater or upper slope of mud volcano \\
\hline
\end{tabular}

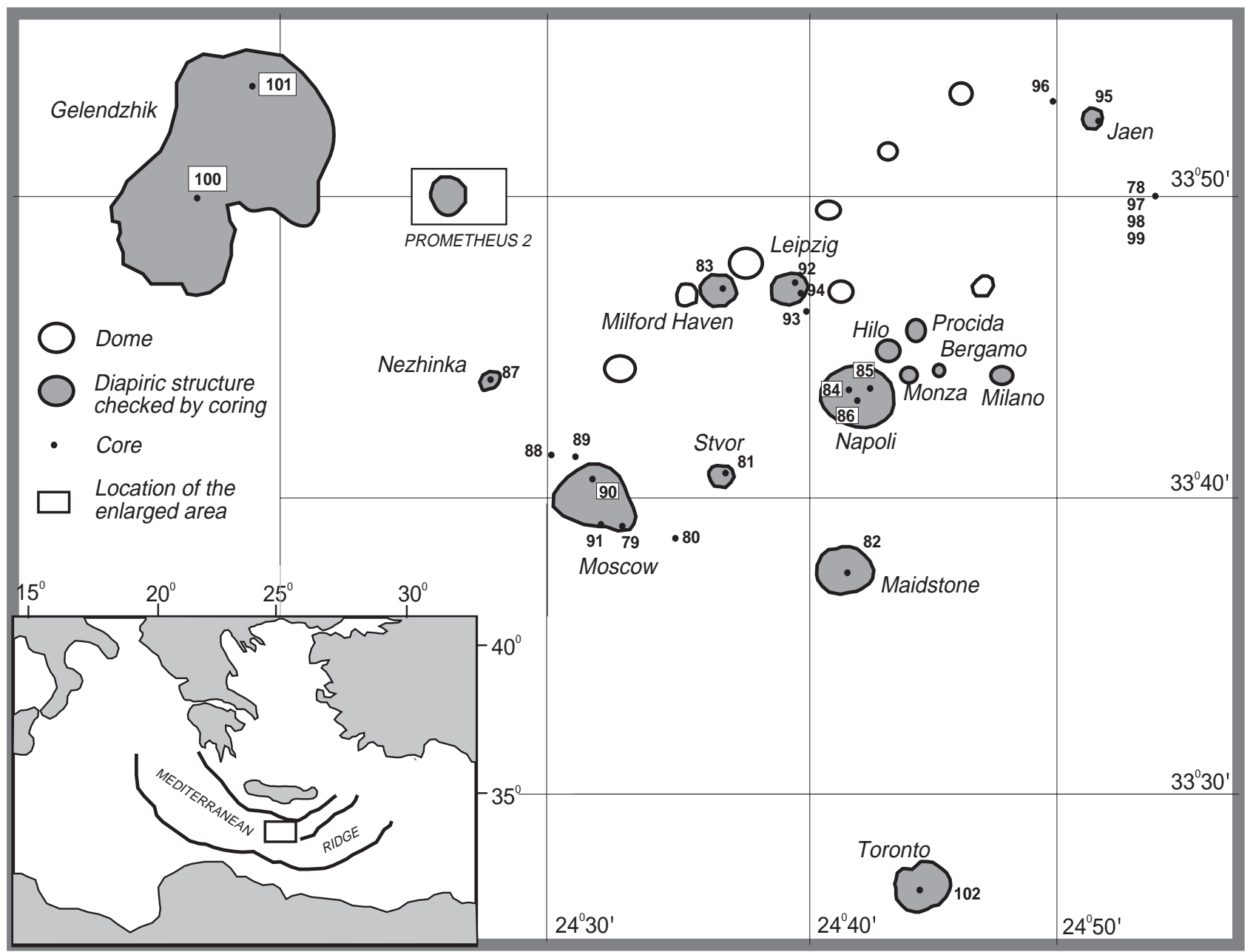

Figure 2. Location of the mud volcanoes of the Olimpi/Prometheus 2 Area, surveyed during Cruise TTR 3, Leg 2 (after Cita et al., 1996).

as in the youngest mud breccia flows. Packed biomicrites were observed among the mud breccia clasts in the samples collected during the TTR-3 expedition and in the Leg 160 samples as well. The different sandstone fragments observed in the ODP mud breccia samples correspond to the subfeldspathic lithic wackes and lithic arenites previously described for the Olimpi area where larger clasts of these rocks were sampled (Akhmanov, 1996). Sedimentary structures of the sandstones have suggested turbiditic origin and deep-sea environments: graded bedding, convoluted lamination, low-angle microcross lamination, gradual transition into siltstones, and other genetic indications (Akhmanov, 1996).

The only limestone type observed in the previously analyzed mud breccia clasts from the Olimpi area, but not observed in the Leg 160 samples of the buried mud breccia flows, were fragments of pel- sparite. Pelsparites are not widespread rocks. Usually, they form rather thin layers interbedded with other types of limestone.

Fragments of pelsparites are the rarest among the clasts from the Olimpi mud breccia (less than 1\%) and were recorded only for the Toronto and Moscow mud volcanoes (Table 3), although large volumes of material from different volcanoes of the Olimpi area were examined (Akhmanov, 1996). The relatively small volume of the ODP samples might have been insufficient for observation of such rare clasts.

The crystalloclasts have all resulted from disintegration of different rock fragments within the mud breccia. The set of crystalloclasts corresponds completely to component compositions of the lithoclasts. Quartz grains, plagioclase grains, potassium-feldspar grains and muscovite are from the subfeldspathic lithic wackes and the lithic 
Table 4. Distribution of the main mud breccia clast types among the Olimpi Area mud volcanoes.

\begin{tabular}{|c|c|c|c|c|c|c|c|c|c|c|}
\hline & \multicolumn{8}{|c|}{ TTR data (after Akhmanov, 1996) } & \multicolumn{2}{|c|}{ Leg 160 samples } \\
\hline & Moscow & Stvor & Maidstone & Milford Haven & Leipzig & Jaen & Gelendzhik & Toronto & Napoli & Milano \\
\hline Packed biomicrites (5\%) & + & + & + & + & + & & & & + & + \\
\hline Micrites $(15 \%)$ & + & & + & + & + & + & + & + & + & + \\
\hline Fossiliferous micrites (10\%) & + & + & + & + & + & + & + & + & + & + \\
\hline Crystalline limestones (4\%) & + & + & + & + & & & + & + & + & + \\
\hline Pelsparites $(1 \%)$ & + & & & & & & & + & & \\
\hline Subfeldspathic lithic wackes (6\%) & + & + & + & + & + & & + & & + & + \\
\hline Lithic arenites (4\%) & + & + & + & + & + & + & + & & + & + \\
\hline Siltstones (5\%) & + & + & + & + & + & + & + & + & + & + \\
\hline Mudstones (50\%) & + & + & + & + & + & + & + & + & + & + \\
\hline
\end{tabular}

Note: $+=$ present. ODP Leg 160 is shown in comparison with TTR data.

arenites. Monocrystals of calcite are from the rocks of the limestone group, or originate as fragments of calcite cement from the lithic arenites. The crystalloclasts observed in the mud breccia samples are usually less than $0.25 \mathrm{~mm}$ and never more than $0.5 \mathrm{~mm}$ in size. This corresponds to the grain-size parameters of the lithoclasts described for the Olimpi mud breccia (Akhmanov, 1996).

Bioclasts in mud breccias probably result from disintegration of rock fragments within mud breccia, like the other clasts. Most of the bioclasts are from carbonate rocks rich in skeletal components. Some may be from lithic arenites (Akhmanov, 1996).

Some results of microscopic study of the mud breccia samples are shown in Figures 3 and 4, which illustrate the lack of regular variation in the mud breccia clast composition with depth in Hole 970A from the Milano mud volcano and in Hole 971B from the Napoli mud volcano, respectively. Absence of some clast types in some samples may be explained by the limited volume of mud breccia sampled on Leg 160, which was insufficient for complete observations of the suite of clasts known to be present from previous studies. No regular variation in the mud breccia clast lithology was noted for the Leg 160 samples. Clay mineral composition of the mud breccia matrix does not vary significantly downhole at either the Leg 160 Milano or Napoli mud volcano sites (Figs. 5, 6).

Examination of the Olimpi mud breccia on the basis of the ODP data shows a lack of significant downhole variation in mud breccia matrix and clast composition. This suggests that the source formations for the mud breccia of the Olimpi Area mud volcanoes have not changed since at least the late Pliocene.

We discussed above the results of the lithological study of the mud breccia from the Olimpi diapiric area only. It is also of value to compare the findings from this particularly well studied mud diapiric field, the Olimpi Field, with results from other areas of mud volcanism along the Mediterranean Ridge. This is especially important to eventually determine variations in geological setting, including source rock variation, and different stress regimes along the Mediterranean Ridge, from compression in the center and west to transpression in the east.

Even very preliminary lithological comparison of the mud breccias sampled from the Olimpi area with those from other known diapiric areas on the Mediterranean Ridge has shown distinct characteristics for each area of development of mud volcanism. The mud breccia of the Cobblestone 3 diapiric area on the western part of the Mediterranean Ridge is different from the Olimpi mud breccia. Very specific fragments of detrital limestone with a large amount of terrigenous constituents, reddish brown mudstone, and siderite aggregate were obtained from the mud breccia clasts from the Aros and Novorossiysk mud volcanoes, and from an unnamed mud volcano (Fig. 1). Clay mineral composition of the matrix differs slightly as well.

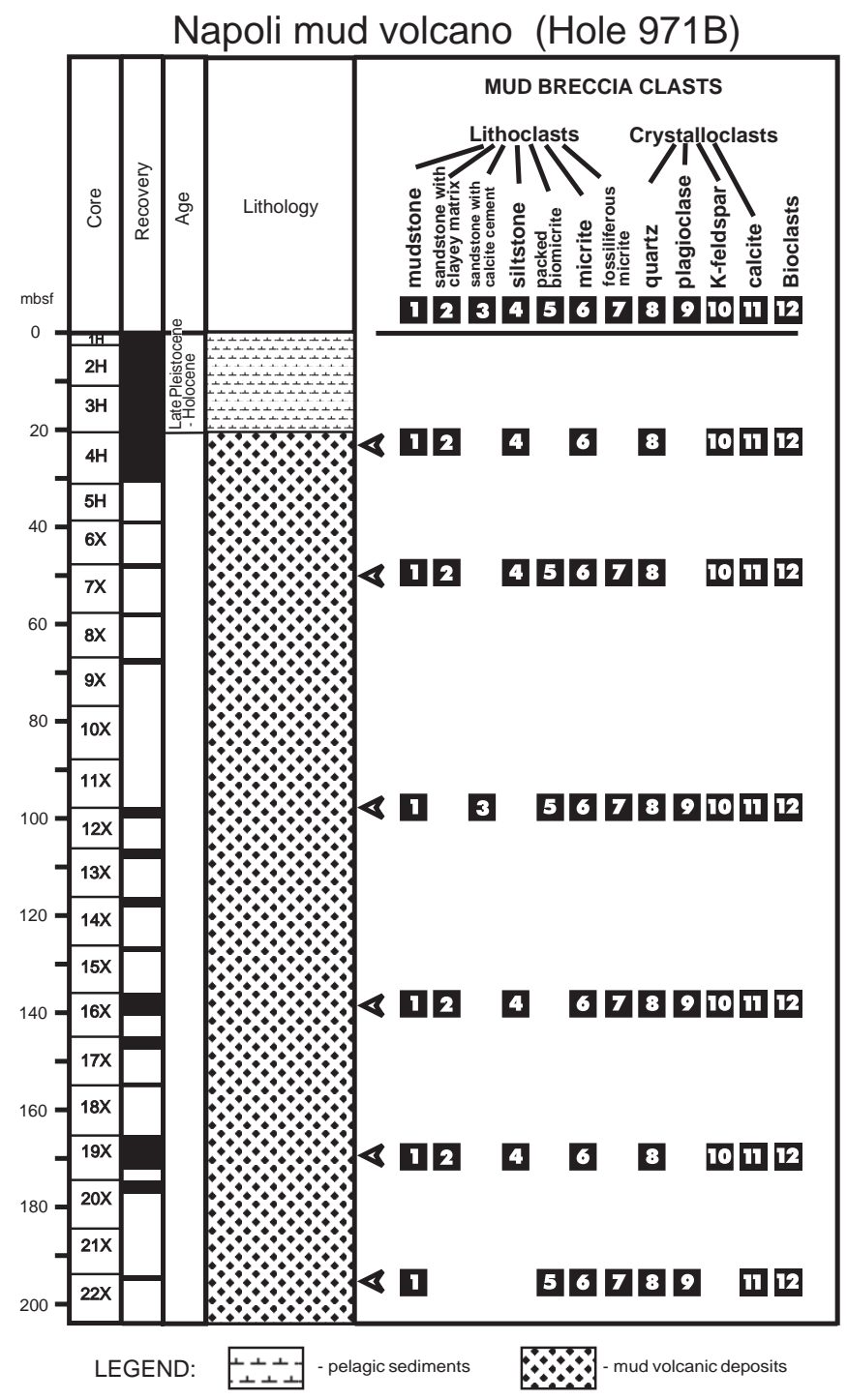

Figure 3. The Napoli mud volcano. Figure shows downhole variation of mud breccia clast composition. Lithology, core recovery, and age information of Hole 971B are adapted from Emeis, Robertson, Richter, et al. (1996). 


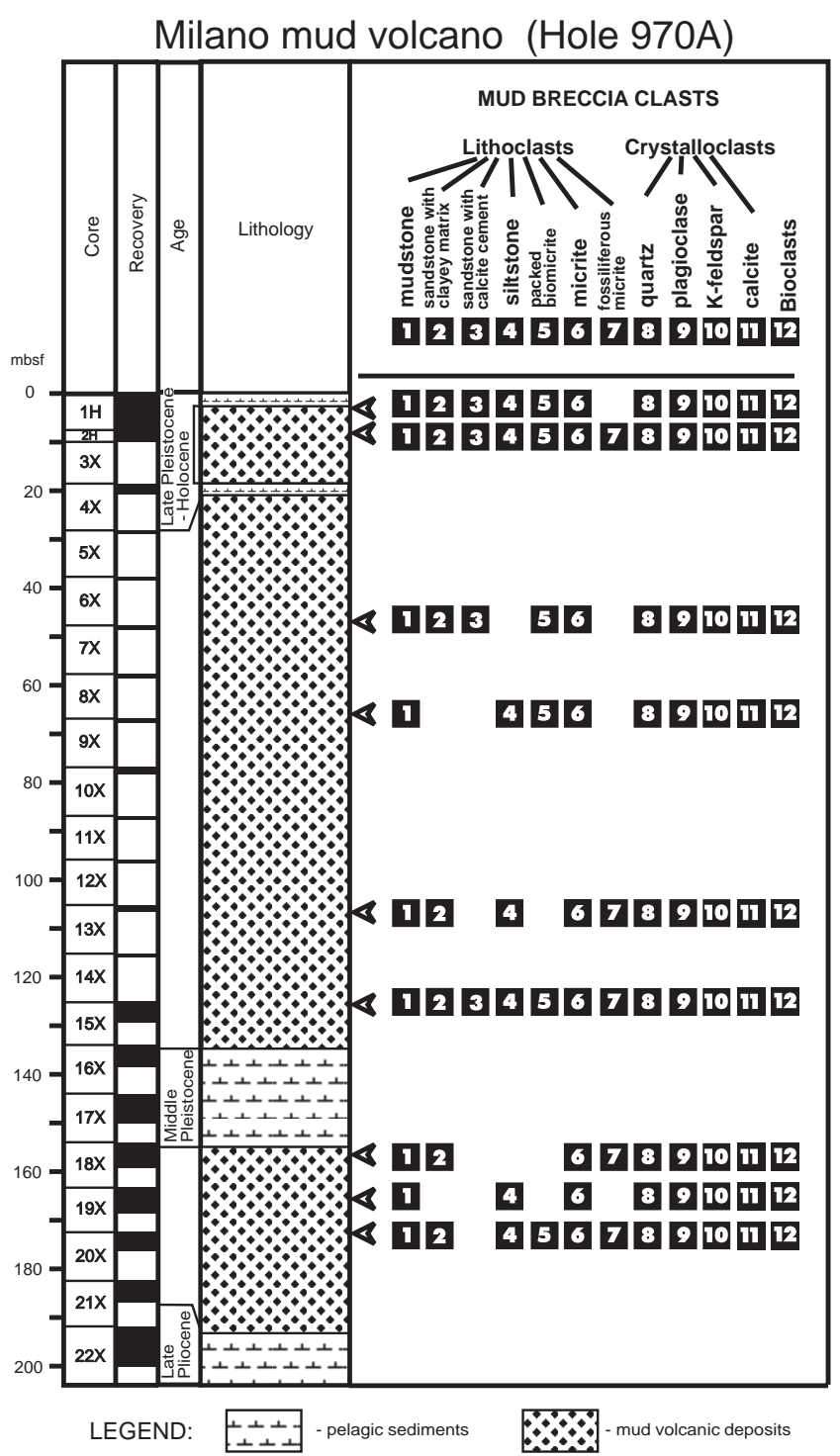

Figure 4. The Milano mud volcano. Figure shows downhole variation of mud breccia clast composition. Lithology, core recovery, and age information of Hole 970A are adapted from Emeis, Robertson, Richter, et al. (1996).

Although recently discovered mud volcanoes of the United Nation Rise diapiric area are located relatively close to the Olimpi Area, the lithology of their mud breccias was found to have many specific features. Light-gray subarkose sandstones, gray bioclastic limestones, and grayish brown mudstones observed in mud breccia samples collected from the Stoke-on-Trent and Dublin mud volcanoes (Fig. 1) were not noted before for other areas of mud volcanism on the Mediterranean Ridge (Cronin et al., 1997).

The specificity of the composition of the mud breccia from different mud volcanic areas of the Mediterranean Ridge reflects peculiarities of source formation lithology and structural tectonic setting of mud volcano roots that are different in different areas of the Eastern Mediterranean. Some common features of the Mediterranean mud breccia lithology were also found. Fragments of dark-gray mudstone,

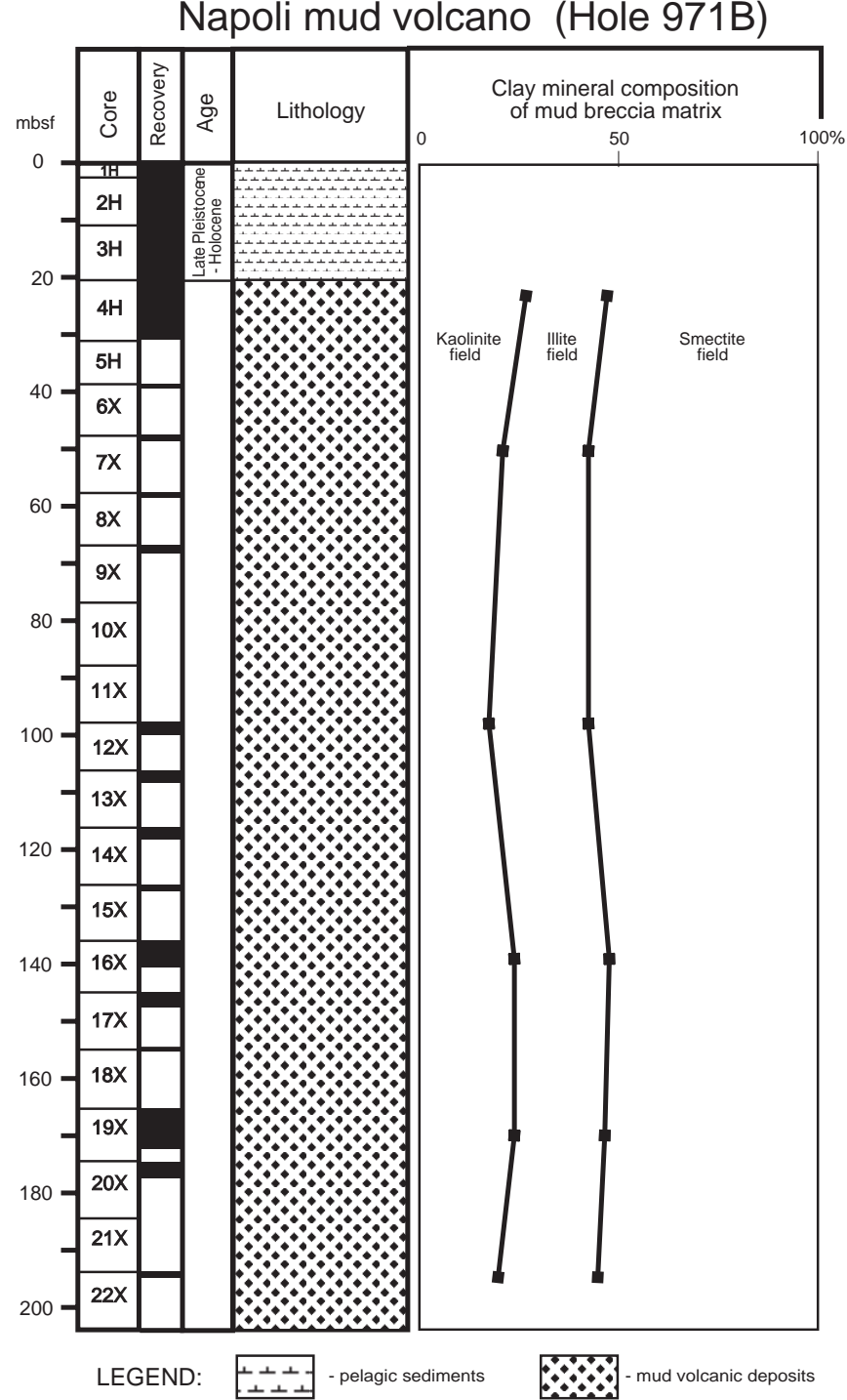

Figure 5. The Napoli mud volcano. Figure shows downhole variation of clay mineral composition of mud breccia matrix. Lithology, core recovery, and age information of Hole 971B are adapted from Emeis, Robertson, Richter, et al. (1996).

light-gray micritic limestone, light yellowish gray marlstone, and light-gray fossiliferous micrite were found in most of mud breccia samples from different areas. Moreover the fragments of these rocks are often prevalent among the lithoclasts, probably corresponding to common sedimentary series widespread in the subsurface of the whole Eastern Mediterranean.

\section{CONCLUSIONS}

The most important findings of the study performed on the ODP samples from the Olimpi mud breccia and their comparison with the previous data may be summarized as follows: 


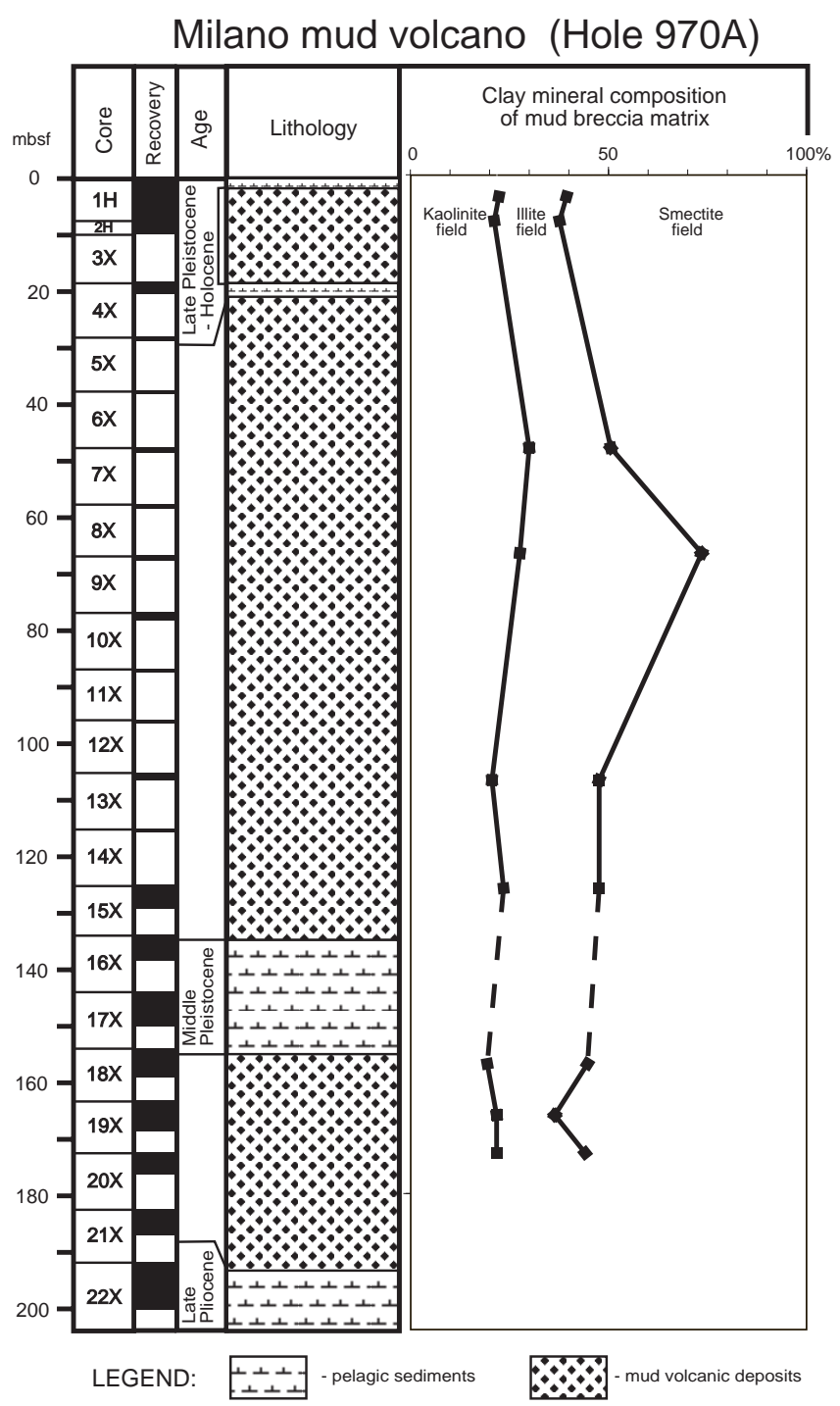

Figure 6. The Milano mud volcano. Figure shows downhole variation of clay mineral composition of mud breccia matrix. Lithology, core recovery, and age information of Hole 970A are adapted from Emeis, Robertson, Richter, et al. (1996).

1. The composition of buried mud breccia flows recovered from the Leg 160 sites is similar to that of samples from other parts of the Olimpi area. The lack of significant differences in the compositions of the mud breccia exposed on the seafloor and the buried mud breccia recovered at the ODP sites suggests that the source series for the Olimpi mud breccia have not changed since at least the late Pliocene.

2. The structural diversity of mud volcanic deposits with depth as observed in thin section can be classified according to the microstructural features into three main types of mud breccia: the most widespread structureless "ordinary mud breccia," which forms the central parts of flows (i.e., middle parts of individual beds); the "organized mud breccia" associated with the outer parts of mud breccia flows (i.e., near the upper or lower contacts); and the "redeposited mud breccia" formed by gravity flows transporting reworked ordinary breccia as local turbidites not far away from the mud volcano.

3. The composition of the mud breccia from different mud volcanic areas known along the Mediterranean Ridge reflects peculiarities and variability of the source formation lithology and structural tectonic setting in different parts of the Eastern Mediterranean. Nevertheless, some common features of the Mediterranean mud breccia may correspond to sedimentary series that extend throughout the entire Eastern Mediterranean.

\section{ACKNOWLEDGMENTS}

The authors wish to thank the Netherlands Foundation for Earth Science for contributions to the TTR Programme and for support of John Woodside in his participation in Leg 160. We wish to express our appreciation to UNESCO, IOC, European Science Foundation, Russian Committee for Geology, and national funding organization of the Russian Federation, the Netherlands, United Kingdom, and Italy for the financial support and encouragement of the TTR Programme. Our thanks are extended to the crews and technical staff of the research vessels Gelendzhik and Professor Logachev and the drilling vessel JOIDES Resolution for their excellent contribution to the success of the cruises. Personal thanks are addressed to Dr. V.L. Luksha, Dr. V.L. Kosorukov, R.M. Almendinguer, and S.V. Bouriak (Moscow State University) for scientific and technical support of the X-ray studies and to P.V. Shashkin for help in preparation of the illustrations. Reviews by Professor M.B. Cita, Dr. B.T. Cronin, and an anonymous reviewer are gratefully acknowledged. The first author would like to thank Dr. M.K. Ivanov and Dr. A.F. Limonov for encouragement to perform the present study and for providing continuous scientific support.

\section{REFERENCES}

Akhmanov, G.G., 1996. Lithology of mud breccia clasts from the Mediterranean Ridge. Mar. Geol., 132:151-164.

Camerlenghi, A., Cita, M.B., Della Vedova, B., Fusi, N., Mirabile, L., and Pellis, G., 1995. Geophysical evidence of mud diapirism on the Mediterranean Ridge accretionary complex. Mar. Geophys. Res., 17:115-141.

Camerlenghi, A., Cita, M.B., Hieke, W., and Ricchiuto, T.S., 1992. Geological evidence for mud diapirism on the Mediterranean Ridge accretionary complex. Earth Planet. Sci. Lett., 109:493-504.

Cita, M.B., Camerlenghi, A., Erba, E., McCoy, F.W., Castradori, D., Cazzani, A., Guasti, G., Giambastiani, M., Lucchi, R., Nolli, V., Pezzi, G., Redaelli, M., Rizzi, E., Torricelli, S., and Violanti, D., 1989. Discovery of mud diapirism in the Mediterranean Ridge: a preliminary report. Boll. Soc. Geol. Ital., 108:537-543.

Cita, M.B., Ivanov, M.K., and Woodside, J. (Eds.), 1996. The Mediterranean Ridge diapiric belt: introduction. Mar. Geol., 132:1-6.

Cita, M.B., Ryan, W.B.F., and Paggi, L., 1981. Prometheus mud-breccia: an example of shale diapirism in the Western Mediterranean Ridge. Ann. Geol. Pays Hellen., 30:543-570.

Cita, M.B., Woodside, J.M., Ivanov, M.K., Kidd, R.B., Limonov, A.F., and Scientific Staff of Cruise TTR3 Leg 2, 1994. Fluid venting, mud volcanoes and mud diapirs on the Mediterranean Ridge. Rend. Fis. Acc. Lin. Roma, 5:161-169.

Cronin, B.T., Ivanov, M.K., Limonov, A.F., Egorov, A., Akhmanov, G.G., Akhmetjanov, A.M., Kozlova, E.V., and Shipboard Scientific Party TTR- 
3, 1997. New discoveries of mud volcanoes on the Eastern Mediterranean Ridge. J. Geol. Soc. London, 154:173-182.

Emeis, K.-C., Robertson, A.H.F., Richter, C., et al., 1996. Proc. ODP, Init. Repts., 160: College Station, TX (Ocean Drilling Program).

Limonov, A.F., Woodside, J.M., Cita, M.B., and Ivanov, M.K., 1996. The Mediterranean Ridge and related mud diapirism: a background. Mar. Geol., 132:7-19.

Premoli-Silva, I., Erba, E., Spezzaferri, S., and Cita, M.B., 1996. Age variation in the source of the diapriric mud breccias along and across the axis of the Mediterranean Ridge Accretionary Complex. Mar. Geol., 132:175-202.
Staffini, F., Spezzaferri, S., and Aghib, F., 1993. Mud diapirs of the Mediterranean Ridge: sedimentological and micropalaeontological study of the mud breccia. Riv. Ital. Paleontol. Stratigr., 99:225-254.

van der Meer, R., 1996. Grading in mud volcanic breccia from the Mediterranean Ridge. Mar. Geol., 132:165-173.

Date of initial receipt: 7 February 1997

Date of acceptance: 5 September 1997

Ms 160SR-045 